\section{Greenland's Policy in the Seventies}

The year 1971 marked the beginning of an epoch in Greenland's policy. The colonial status of the island had been abolished a couple of decades before, and efforts had been initiated to introduce comprehensive reforms. The goal to be achieved was a rapid improvement of the population's standard of living, and during the following years the political authorities in Denmark and Greenland were generally agreed on the course of development, which was supported by substantial contributions of Danjsh capital and manpower.

At the election of the Provincial Council in Greenland in 1971 a new generation came to the fore, and several young politicians were elected whose attitude to the policy so far pursued was very critical. That same year witnessed the election of Moses Olsen, a young Greenlander teaching at the folk high school. Olsen, who was very critical of Danish sovereignty in Greenland, was elected member of Parliament for the southern constituency, and Knud Hertling, a lawyer born in Greenland, who was reelected as representative of the northern constituency, became a member of the new Social Democrat minority government. Because of the weak position of the minority government in Parliament the votes of the two Greenland M.P.'s became of paramount importance, for in recent years Greenlanders' points of view in political issues have carried more weight than heretofore.

This new situation had already been reflected in the speech delivered by the Danish Prime Minister at the opening of Parliament in October 1971, in the course of which he stated:

"Insofar as Greenland is concerned, it will be the Government's aim to take the principles applied in the Greenland policy up for revaluation so that developments to the greatest extent possible may be allowed to depend on the people's own resources."

This part of the speech from the Throne was undoubtedly inspired by the desire expressed by Knud Hertling, the Minister, and the young politicians, that Greenland's policy should be critically revised.

Elections in Greenland are not run on party lines, and the young politicians have set up no general platform, but from the opinions advanced by them in recent years a number of joint fundamental views have taken form.

Insofar as the Greenlanders are concerned it is recognized that the political reforms have resulted in a considerable improvement in the material conditions of life, but it is maintained that the price has been too high. Serious social problems have followed in the wake of the rapid development, and the cultural life of Greenland has been endangered by the concentrated Danish humanitarian effort. The young people want a continuation of the policy of development, but at a slower pace, and with more consideration for the needs of the villages and the hunting districts. They want the political agencies in Greenland to be given added power, and think that the educational policy should be changed. More weight should be attached to Greenlandic within the schools, and the educational program should be planned to meet requirements in Greenland rather than just being a copy of the educational system in Denmark. The Danish influence making itself so heavily felt within the sector of private business in Greenland should be limited, e.g. through subsidies to Greenland's cooperatives. It is considered impracticable to achieve the same standard of living in Greenland as in Denmark; for that purpose the resources so far known to be available in Greenland are insufficient, but apart from that the Greenlanders want to be allowed to decide their own affairs.

Actually, the claim for greater influence for Greenland in questions of local policy is not of recent date. In about 1860 the seeds of local government were already sown in Greenland, and in the course of developments slow progress was made until 1908 when local councils were introduced and 1950 when municipal self-government became a fact. In 1950 a Provincial Council was elected for Greenland as a whole. All fundamental questions concerning Greenland are put before that Council which since 1957 has been responsible for the administration of the entire social apparatus. In addition, as mentioned previously, Greenland is represented in the Danish Parliament by two M.P.'s elected by the Greenlanders.

Life in Greenland, however, still bears the stamp of government administration within most public sectors. A government committee appointed in 1970 has given birth to a number of reports with recommendations for delegation of important central government functions to the local councils in Greenland. It is expected that by the end of the 1970s the local administration, roads, power plants, schools, etc. will have been taken over entirely by the Greenlanders themselves. The role of the central government will be limited to the granting of subsidies in amounts which, on the whole, will be based on the number of inhabitants in each municipality.

These proposed reforms, however, apparently do not satisfy the young politicians, 
who want to go even further and whose ultimate goal is Home Rule. Prior to 1971 no responsible Greenland politician had ever advanced any such request, but political events in recent years, including especially the discussion about fishing limits and the referendum on Danish membership in the European Community, have given added impetus to the claim for Home Rule. At the referendum in October 1972 concerning Denmark's membership in the Common Market 70 per cent of the votes cast in Greenland were against. The Greenland electorate is growing to realize that in the case of important political issues Greenland's interests do not always coincide with the interests of Denmark as a whole.

Impressed by the results of the EEC-referendum the Provincial Council asked the Danish Government to have a committee appointed to investigate the possibilities of Home Rule in Greenland, and in January 1973 the Minister for Greenland, Mr. Hertling, acted on that request. All members of the committee are Greenlanders, but it is not expected that the committee will submit its report during the first four or five years.

One of the most difficult questions in connection with Home Rule for Greenland is how to combine any such system with the subsidy arrangement under which the Danish Government at the moment contributes Dkr. 700 million a year to Greenland. Normally, Home Rule would involve economic independence, but it is a serious question whether the economic resources of Greenland would be sufficient to finance the community in the process of development. The principal industry of Greenland - the fisheries - has during recent years been faced with considerable difficulties owing to an unfavourable climatic change, overfishing and international restrictions. Economically, the picture may change, however, in case of a successful outcome of the prospecting for minerals and oil and the exploration activities which have been going on in recent years. In any case the royalties, viewed in the long term, should improve the economic balance in Greenland. For the time being serious consideration of the introduction of Home Rule must primarily be concentrated on finding a solution to the problem of the subsidy arrangement which would give the Greenland politicians a greater infuence in allotting the funds but would at the same time be acceptable to the Danish politicians and taxpayers.

In connection with the Home Rule issue no desire has been expressed for complete severance from Denmark. On the contrary, one of the most fervent advocators of Home Rule for Greenland, Moses Olsen, has publicly stated: "One thing I have never had in mind is a dissolution of our national union. For that, Greenland and Denmark have too many historical traditions in common-notwithstanding the great differences between them both from a cultural, geographic and industrial point of view."

The development of Greenland's policy during the coming years will be exciting. Quite a few Greenlanders are opposed to the outspokenness of the new politicians and find their views too radical. It is now a question of whether the young politicians can manage to stick together and whether they will be able to win the sympathy of the general public in Greenland for their views before the election of the Provincial Council in 1975.

Claus Bornemann Grønlandsrådet, Denmark

\section{Sampling of Glacial Snow for Pesticide Analysis on the High Plateau Glacier of Mount Logan}

Recently there have been a number of attempts to determine the presence of pollutants in remote areas of the world. The snow of giaciers is a particularly interesting subject for such work, since it contains a record of past years as well as the present. It has been shown 1 that there is a clear correlation between the lead concentration in old snow strata and the level of worldwide industrial activity. Such pollutants are transported by the atmosphere, and it is especially interesting to know if they are present in precipitation that forms at high altitude. As part of the Ice Field Ranges Research Project (IRRP) of 19702, we undertook the study of another common pollutant, the pesticide DDT. Here we report on our attempt to develop techniques for taking snow samples at high altitude in locations where work had to be done under adverse conditions, and with simple equipment.

Samples were taken at an elevation of 5,364 metres on Mount Logan, Yukon Territory, Canada. The arduous work of sampling was carried out by the IRRP High Altitude Support Team. Conditions at the site were quite hostile. The work was performed at temperatures below $-20^{\circ} \mathrm{C}$., and often in high winds. At this elevation the effects of hypoxia are quite marked, and the workers, though acclimatized by many weeks at altitude, became quickly exhausted. Psychological effects are equally important. Work was constantly hampered by a feeling of lassitude and an impairment of judgement. 